\title{
PENGARUH KINERJA DAN VOLUME PERDAGANGAN TERHADAP HARGA SAHAM PERUSAHAAN PADA INDUSTRI PERBANKAN
}

\author{
Saiful Anam ${ }^{*}$ \\ Program Studi Akuntansi, STIE Al-Anwar, Mojokerto, Indonesia
}

DOI: https://doi.org/10.24123/jati.v14i2.4662

\begin{abstract}
The aim of this study is to (1) determine the effect of Return On Asset towards the Stock Price of banking companies in Indonesia Stock Exchange (2) determine the effect of Return On Equity towards the Stock Price of banking companies in Indonesia Stock Exchange (3) determine the effect of Earning Per Share towards the Stock Price of banking companies in Indonesia Stock Exchange (4) determine the effect of Trading Volume towards the Stock Price of banking companies in Indonesia Stock Exchange (5) determine the effect of Return On Asset, Return On Equity, Earning Per Share and Trading Volume towards the Stock Price of banking companies in Indonesia Stock Exchange.

The population in this study is banking companies listed in the IDX. The selection of samples applies the purposive sampling method. The number of samples is 10 banking companies listed on the IDX in the period of 2015-2018. The data analysis used to test the hypothesis is the Multiple regression analysis technique. Based on the research, results show that (1) Return On Asset gives positive effect towards the Stock Prices (2) Return On Equity Asset have an insignificant effect towards the Stock Prices (3) Earning Per Share Asset gives positive effect towards the Stock Prices (4) Trading Volume Asset have an insignificant effect towards the Stock Prices.
\end{abstract}

Keywords: Earning Per Share; Return On Asset; Return On Equity; Stock Price; Trading Volume.

\begin{abstract}
Abstrak
Penelitian ini bertujuan untuk (1) mengetahui pengaruh Return On Asset terhadap Harga Saham perusahaan perbankan di Bursa Efek Indonesia (2) mengetahui pengaruh Return On Equity terhadap Harga Saham perusahaan perbankan di Bursa Efek Indonesia (3) mengetahui pengaruh Earning Per Share terhadap Harga Saham perusahaan perbankan di Bursa Efek Indonesia (4) mengetahui pengaruh Volume Perdagangan terhadap Harga Saham perusahaan perbankan di Bursa Efek Indonesia (5) mengetahui pengaruh Return On Asset, Return On Equity, Earning Per Share dan Volume Perdagangan terhadap Harga Saham perusahaan perbankan di Bursa Efek Indonesia.

Populasi pada penelitian ini adalah perusahaan perbankan yang terdaftar di BEI. Pemilihan sampel menggunakan metode purposive sampling. Jumlah sampel sebanyak 10 perusahaan perbankan yang terdaftar di BEI pada periode 2015-2018. Analisis data yang digunakan untuk menguji hipotesis adalah dengan menggunakan teknik analisis regresi berganda.

Berdasarkan hasil penelitian menunjukkan bahwa (1) Return On Asset berpengaruh positif terhadap Harga Saham (2) Return On Equity tidak berpengaruh terhadap Harga Saham (3) Earning Per Share berpengaruh positif terhadap Harga Saham (4) Volume Perdagangan tidak memengaruhi terhadap Harga Saham.
\end{abstract}

Kata Kunci: Earning Per Share; Harga Saham; Return On Asset; Return On Equity; Volume Perdagangan. 


\section{PENDAHULUAN}

Perusahaan adalah organisasi yang didirikan oleh seseorang atau sekelompok orang atau lembaga lain, yang kegiatannya memenuhi kebutuhan ekonomi manusia untuk produksi dan distribusi. Tujuan perusahaan adalah memaksimalkan nilai perusahaan dan membuat pemegang saham sejahtera. Memaksimalkan nilai pemegang saham dapat dicapai dengan memaksimalkan nilai sekarang atau nilai sekarang dari semua keuntungan pemegang saham yang diharapkan akan diperoleh di masa yang akan datang. (Dominic-Managerial Economic). Harga saham dapat berfluktuasi setiap saat, tergantung dari penawaran dan permintaan saham oleh investor. Faktor yang dapat menyebabkan fluktuasi harga saham perusahaan adalah faktor internal perusahaan dan faktor eksternal perusahaan. Penelitian ini menggunakan faktor internal perusahaan dan faktor eksternal yang tercermin dalam laporan keuangan perusahaan. Faktor internal perusahaan yang digunakan berupa rasio keuangan, seperti rasio laba yang dirumuskan dengan return on asset (ROA), return on equity (ROE) dan rasio pasar diganti dengan earning per share (EPS), serta volume perdagangan sebagai mewakili faktor eksternal. Tujuan dalam penelitian ini lebih pada pengujian hubungan antar variabel sehingga dapat mengetahui secara empiris pengaruh Return on Asset, Retun On Equity, Earning Per Share dan Volume Perdagangan baik secara langsung maupun secara simultan terhadap Harga Saham Perusahaan Perbankan yang terdaftar di BEI tahun 2015-2018.

\section{TELAAH TEORETIS}

\section{Return On Asset}

Return on asset (ROA) merupakan faktor probabilitas yang mengukur efektivitas penggunaan aset suatu perusahaan untuk menghasilkan laba (Husnan, 2010). Indikator ROA merupakan salah satu indikator keuangan yang paling sering digunakan untuk mengevaluasi kinerja perusahaan. Jika kinerja suatu perusahaan semakin baik maka tingkat pengembaliannya akan semakin tinggi.

Menurut Eduardus Tandelilin (2010: 372), ROA merupakan laba atas aset yang menggambarkan bagaimana kinerja perusahaan menghasilkan laba.

Rumus ROA dapat digunakan sebagai berikut ( Dr Kasmir,2017:202):

$$
R O A=\frac{\text { Laba sesudah bunga dan pajak }}{\text { Total asset }} \times 100 \%
$$




\section{Return On Equity}

Pendapat Kashmir (2017: 204) mengemukakan bahwa return to equity atau ROE adalah rasio modal untuk mengukur laba setelah pajak. Rasio ini menunjukkan penggunaan modal yang efektif. Semakin tinggi proporsinya, mencerminkan nilai yang semakin baik, dan sebaliknya. Menurut Brigham dan Houston (2010:149), pengertian ROE adalah rasio keuntungan bersih terhadap ekuitas yang mengukur tingkat pengembalian atas investasi pemegang saham biasa. Rumus dari Return on Equity (ROE) yang dapat digunakan seperti di bawah ini :

$$
R O E=\frac{\text { Laba sesudah bunga dan pajak }}{\text { Modal }} \times 100 \%
$$

\section{Earning Per Share}

Bagi hasil atau harga buku setiap saham merupakan tolak ukur tingkat keberhasilan manajemen dalam memperoleh keuntungan atas saham tersebut. Rasio yang lebih rendah berarti bahwa manajemen tidak dapat berhasil memuaskan pemegang saham. Sebaliknya, dengan bertambahnya rasio laba per lembar saham, kesejahteraan pemegang saham akan meningkat, artinya, tingkat pengembalian yang lebih tinggi. Penghasilan pemegang saham adalah penghasilan setelah pajak. Keuntungan yang tersedia bagi pemegang saham biasa adalah jumlah pendapatan yang dikurangkan dari pajak, dividen, dan hak-hak pemegang saham yang memenuhi saham prioritas. (Kashmir: 2017).

Rumus untuk mencari EPS :

$$
E P S=\frac{\text { Laba saham biasa }}{\text { Saham biasa yang beredar }} \times 100 \%
$$

\section{Volume Perdagangan}

Volume transaksi perdagangan mengacu pada harga yang dikeluarkan perusahaan yang menerbitkan sekuritas di pasar modal pada setiap hari perdagangan. Harga tersebut sudah termasuk pada tingkat harga yang dinegosiasikan oleh pembeli dan dijual melalui pialang perdagangan saham di pasar modal. Volume perdagangan saham sangat penting bagi investor, karena bagi investor volume perdagangan saham mencerminkan status sekuritas yang diperdagangkan di pasar modal. Bagi investor, sebelum berinvestasi atau setelah berinvestasi, yang terpenting adalah tingkat keamanan likuiditas. (Wahyu dan Wijayanto, 2005)

Volume perdagangan adalah bagian dari analisis teknis yang diakui. Aktivitas perdagangan yang tinggi dan volume perdagangan di bursa akan diartikan sebagai tanda bahwa pasar akan 
membaik (bullish). Volume perdagangan yang meningkat dikombinasikan dengan kenaikan harga merupakan tanda-tanda meningkatnya situasi bullish. (Suad Husnan, 2001)

\section{Harga Saham}

Saham merupakan salah satu efek yang dijual di BEI selain obligasi dan sertifikat. Pendapat Simamora (2000: 408) mendefinisikan saham sebagai unit kepemilikan saham perusahaan. Harga pasar adalah harga yang ditetapkan di pasar perdagangan saham. Harga pasar adalah harga saham karena penawaran dan permintaan bursa. Harga saham juga dapat diartikan sebagai harga yang dibentuk oleh interaksi antara pembeli dan penjual terhadap ekspektasi keuntungan perusahaan. Harga penutupan adalah harga permintaan yang diajukan oleh penjual atau harga transaksi terakhir selama periode waktu tertentu.

Menurut Fred dan Copeland (1999: 166), saham merupakan tanda kepemilikan seseorang atau badan dalam suatu perusahaan. Saham adalah selembar kertas yang menyatakan bahwa pemilik yang dimaksud adalah pemilik perusahaan yang menerbitkan saham (terlepas dari pembagian atau jumlahnya).

\section{Kerangka Pemikiran}

Sebelum berinvestasi di saham, investor juga harus mengetahui status perusahaan tempat mereka akan berinvestasi. Biasanya, investor akan meninjau dan menganalisis laporan keuangan perusahaan, dan analisis ini terkait langsung dengan kinerja perusahaan itu sendiri. Dalam penelitian ini, variabel yang dimaksud meliputi variabel dependen (variabel terikat) yaitu harga saham dan variabel independen (variabel bebas) yaitu return on assets, return on equity, earning per share dan volume perdagangan.

Berdasarkan landasan teori yang telah diuraikan diatas serta hubungan antar variabel dari hasil penelitian sebelumnya, maka kerangka pemikiran dalam penelitian ini adalah sebagai berikut:

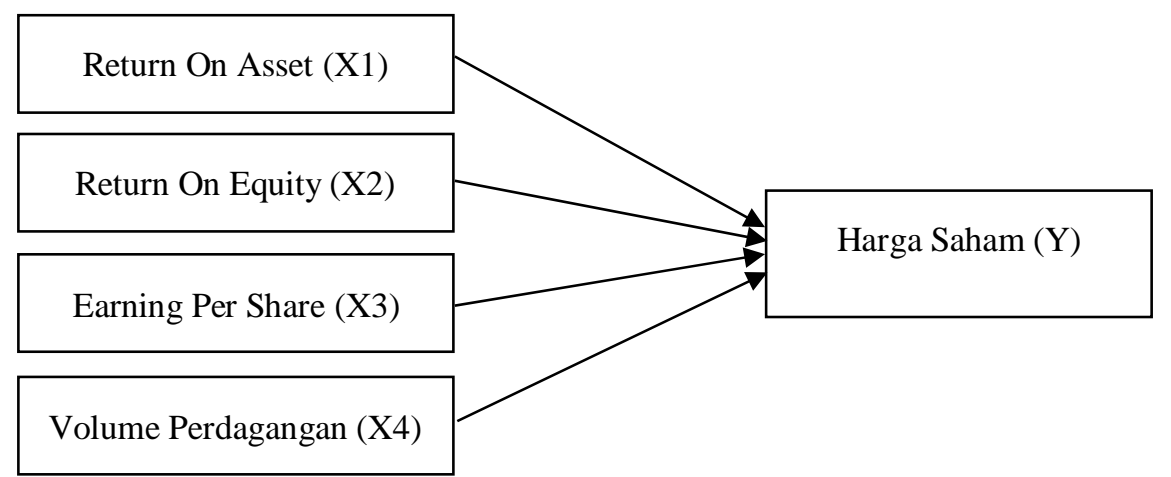

\section{Gambar 1. Kerangka Pemikiran}




\section{Hipotesis Penelitian}

Hipotesis penelitian yang diajukan dalam penelitian ini yaitu:

1) Diduga ROA memiliki pengaruh signifikan terhadap harga saham pada perusahaan perbankan di Bursa Efek Indonesia.

2) Diduga ROE memiliki pengaruh signifikan terhadap harga saham pada perusahaan perbankan di Bursa Efek Indonesia.

3) Diduga EPS memiliki pengaruh signifikan terhadap harga saham pada perusahaan perbankan di Bursa Efek Indonesia.

4) Diduga Volume Perdagangan memiliki pengaruh signifikan terhadap harga saham pada perusahaan perbankan di Bursa Efek Indonesia.

5) Diduga ROA, ROE, EPS dan Volume Perdagangan memiliki pengaruh secara simultan signifikan terhadap harga saham pada perusahaan perbankan di Bursa Efek Indonesia.

\section{METODE}

\section{Jenis Penelitian}

Jenis data secara kategori dalam penelitian ini termasuk kedalam kriteria data kuantitatif deskriptif yaitu data yang bersumber data sekunder.

\section{Populasi dan Sampel}

Prosedur penentuan sampel dalam penelitian ini, penulis menggunakan purpose sampling dalam penentuan sampelnya. Dengan kriteria sebagai berikut:

1) Perusahaan perbankan yang masuk dalam Bursa Efek Indonesia

2) Perusahaan perbankan yang mengeluarkan laporan keuangan maupun laporan tahunan selama periode 2015-2018, baik secara fisik maupun melalui website www.idx.co.id.

3) Perusahaan perbankan yang tidak delisting pada periode 2015-2018.

\section{Daftar Perusahaan Sampel Penelitian}

\section{Tabel 1. Sampel Penelitian}

\begin{tabular}{lll}
\hline No & Kode & Nama Bank \\
\hline 1 & BBCA & Bank Central Asia \\
2 & BBNI & Bank Negara Indonesia (Persero) \\
3 & BBRI & Bank Rakyat Indonesia (Persero) \\
4 & BMRI & Bank Mandiri (Persero) \\
5 & BNGA & Bank CIMB Niaga \\
6 & BNII & Bank Maybank Indonesia
\end{tabular}




\begin{tabular}{lll}
7 & BBTN & Bank Tabungan Negara (Persero) \\
8 & BMAS & Bank Maspion Indonesia \\
9 & NISP & Bank OCBC NISP \\
10 & PNBN & Bank Pan Indonesia \\
\hline
\end{tabular}

\section{Metode Pengumpulan Data}

Sumber data yang digunakan adalah data kuantitatif laporan keuangan dan laporan tahunan yang diambil dari www.idx.co.id dan website perusahaan mulai tahun 2015-2018.

\section{Metode Analisis Data}

Metode analisis data yang dilakukan dengan berpedoman pada data yang diperoleh dari data sekunder berupa laporan keuangan dan laporan tahunan mulai tahun 2015-2018 dan selanjutnya dilakukan uji asumsi klasik dan dianalisis dengan Analisis regresi berganda. Berikut ini definisi operasional variabel dalam mengukur variabel dependen dan independen:

\section{Return On Asset (X1)}

ROA digunakan sebagai alat pengukuran kemampuan perusahaan dalam memperoleh keuntungan dari aset. Rasio ini digunakan untuk mengukur pengembalian investasi yang dapat diperoleh perusahaan dari semua asetnya.

$$
R O A=\frac{\text { Laba sesudah bunga dan pajak }}{\text { Total Asset }} \times 100 \%
$$

\section{Return On Equity (X2)}

ROE adalah ukuran perbandingan yang digunakan sebagai alat ukuran keberhasilan perusahaan dalam menghasilkan pendapatan pemegang saham dengan membagi pendapatan setelah pajak dengan total ekuitasnya.

$$
R O E=\frac{\text { Laba sesudah bunga dan pajak }}{\text { Modal }} \times 100 \%
$$

\section{Earning Per Share (X3)}

Earning per share merupakan ukuran perbandingan untuk mengukur kapabilitas perusahaan dalam menghasilkan profit per lembar saham. EPS dapat dihitung dengan rumus:

$$
E P S=\frac{\text { Laba saham biasa }}{\text { Saham biasa yang beredar }} \times 100 \%
$$




\section{Volume Perdagangan (X4)}

Volume perdagangan yaitu jumlah penjualan lembar saham yang dilakukan oleh sebuah perusahaan yang diperjualbelikan dalam pasar saham, dimana harga telah disepakati oleh penjual dan pembeli saham melalui perantara perdagangaan saham.

\section{Harga Saham (Y)}

Variabel terikat (Y) dalam penelitian ini adalah harga saham bulanan untuk masing-masing perusahaan yang menjadi sampel, dimana harga yang dipergunakan adalah harga penutupan (close price) bulanan tahun 2015-2018. Data harga saham diukur dengan satuan Rupiah.

\section{HASIL PENELITIAN DAN PEMBAHASAN}

\section{Hasil penelitian}

Analisis Data Deskriptif

Tabel 2. Deskripsi Data Penelitian

\begin{tabular}{lrrrrr}
\hline & $\begin{array}{c}\text { N } \\
\text { Statistic }\end{array}$ & \multicolumn{2}{c}{ Statistic } & Statistic & \multicolumn{1}{c}{$\begin{array}{c}\text { Statistic } \\
\text { Statistic }\end{array}$} \\
\hline ROA & 40 & 0,002 & 0,031 & 0,016 & 0,008 \\
ROE & 40 & 0,015 & 0,225 & 0,114 & 0,049 \\
EPS & 40 & 10,440 & 1048,540 & 276,492 & 290,700 \\
Volume & 40 & 241717 & 2913127917 & 495851036,730 & 724800065,090 \\
Perdagangan & 40 & 182 & 23617 & 3804,080 & 5268,099 \\
Harga Saham & 40 & & & & \\
Valid N (listwise) & & & & \\
\hline
\end{tabular}

\section{Sumber : output SPSS Regresi Analysis, data diolah.}

Berdasarkan tabel di atas, jumlah data yang digunakan dalam penelitian ini menunjukkan tidak kurang dari 40 sampel yang diteliti antara tahun 2015 hingga 2018. Berdasarkan hasil perhitungan di atas, capaian terendah laba terhadap aset tampak sebesar 0,002, tertinggi 0,031 , rata-rata 0,016, dan standar deviasi 0,008.

Return on equity memiliki nilai minimum 0,015 , nilai maksimum 0,225 , nilai rata-rata 0,114 , dan nilai standar deviasi 0,049. Nilai minimum variabel EPS adalah 10,440, nilai maksimum 1048,540, nilai rata-rata 276,492, dan standar deviasi 290,700. Nilai minimum variabel volume transaksi adalah 241717, nilai maksimum 2913127917, nilai rata-rata 495851036,730, dan nilai standar deviasi 724800065,090. Nilai minimum variabel harga saham 182, nilai maksimum 23617, nilai rata-rata 3804,080, dan standar deviasi 5268,099. 


\section{Uji Asumsi Klasik \\ Uji Normalitas}

Tabel 3. Hasil Uji Normalitas

\begin{tabular}{llr}
\hline & & $\begin{array}{c}\text { Unstandardized } \\
\text { Residual }\end{array}$ \\
\hline $\mathrm{N}$ & Mean & 40 \\
Normal Parameters & & 0,000 \\
& Std. Deviation & 1565,416 \\
Most Extreme Differences & Absolute & 0,115 \\
& Positive & 0,106 \\
Test Statistic & Negative & 0,115 \\
Asymp. Sig. (2-tailed) & & 0,115 \\
\hline
\end{tabular}

Berdasarkan uji Kolmogorov-Smirnov yang ditunjukkan pada Tabel 3 di atas, nilai probabilitas Asymp.Sig ( 2 sisi) adalah 0,198. Oleh karena nilai probabilitasnya lebih besar dari 0,05 atau $0,198>0,05$, maka data penelitian dikategorikan berdistribusi normal.

\section{Uji Autokorelasi}

Tabel 4. Hasil Uji Autokorelasi

\begin{tabular}{rrrrrr}
\multicolumn{6}{c}{ Model Summary $^{\mathbf{b}}$} \\
\hline Model & R & R Square & $\begin{array}{c}\text { Adjusted R } \\
\text { Square }\end{array}$ & $\begin{array}{c}\text { Std. Error of } \\
\text { the Estimate }\end{array}$ & $\begin{array}{l}\text { Durbin- } \\
\text { Watson }\end{array}$ \\
\hline 1 & $0,955^{\mathrm{a}}$ & 0,912 & 0,902 & 1652,449 & 1,371 \\
\hline
\end{tabular}

a. Predictors: (Constant), Volume Perdagangan, EPS, ROA, ROE

b. Dependent Variable: Harga Saham

Pada tabel 4 dapat dilihat bahwa nilai Durbin Watson untuk penelitian ini adalah sebesar 1,371. Dinyatakan tidak terjadi autokorelasi positif jika $\mathrm{dl}<\mathrm{d}<\mathrm{du}$, maka 1,284 $<1,371<1,720$ berarti model persamaan regresi tidak terjadi autokorelasi.

\section{Uji Heteroskedastisitas}

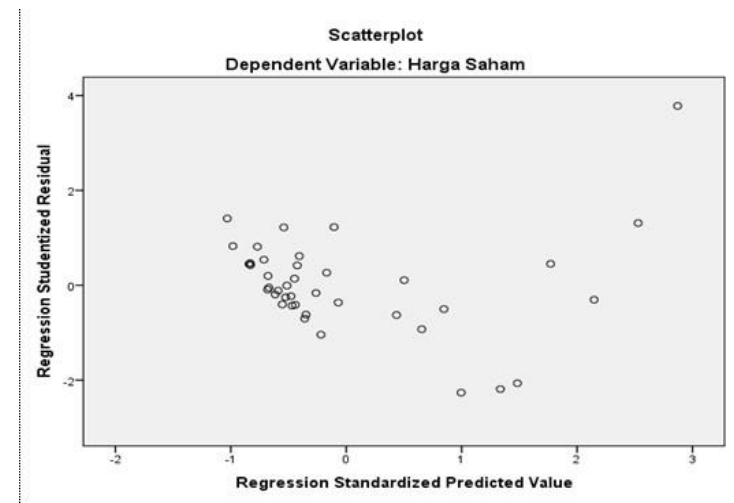

Gambar 1. Hasil Uji Heteroskedastisitas 
Berdasarkan Gambar 1 grafik scatter plot terlihat bahwa data berupa titik-titik yang tersebar merata di atas atau di bawah atau di sekitar titik nol, tidak hanya berkumpul di atas atau di bawah, sebaran titik dan data tidak membentuk pola atau model tertentu. Kemudian model tersebut menyempit dan melebar kembali, dan titik-titik data tersebut menyebar, sehingga dapat disimpulkan bahwa model regresi yang digunakan tidak memiliki heteroskedastisitas.

\section{Uji Multikolinearitas}

Tabel 5. Hasil Uji Multikolinearitas

\begin{tabular}{|c|c|c|c|c|c|c|c|}
\hline \multirow[t]{2}{*}{ Model } & \multicolumn{2}{|c|}{$\begin{array}{l}\text { Unstandardized } \\
\text { Coefficients }\end{array}$} & \multirow{2}{*}{$\begin{array}{c}\text { Standardized } \\
\text { Coefficients } \\
\text { Beta } \\
\end{array}$} & \multirow[t]{2}{*}{$\mathbf{T}$} & \multirow[t]{2}{*}{ Sig. } & \multicolumn{2}{|c|}{$\begin{array}{c}\text { Collinearity } \\
\text { Statistics }\end{array}$} \\
\hline & B & Std. Error & & & & Tolerance & VIF \\
\hline 1 (Constant) & $-1800,270$ & 933,614 & & $-1,928$ & 0,062 & & \\
\hline ROA & 3458,360 & 907,711 & 0,497 & 3,810 & 0,001 & 0,148 & 6,747 \\
\hline ROE & $-279,978$ & 146,305 & $-0,259$ & $-1,914$ & 0,064 & 0,138 & 7,234 \\
\hline EPS & 13,638 & 1,709 & 0,753 & 7,980 & 0,000 & 0,284 & 3,525 \\
\hline $\begin{array}{l}\text { Volume } \\
\text { Perdagangan }\end{array}$ & $-0,000$ & 0,000 & $-0,144$ & $-1,699$ & 0,098 & 0,353 & 2,832 \\
\hline
\end{tabular}

a. Dependent Variable: Harga Saham

Hasil uji multikolonieritas pada tabel 5 diatas menunjukkan:

a. Nilai VIF untuk variabel ROA 6,747 < 10 dan nilai tolerance $0,148>0,100$ maka variabel ROA dinyatakan tidak terjadi multikolonieritas.

b. Nilai VIF untuk variabel $\operatorname{ROE} 7,234<10$ dan nilai tolerance $0,138>0,100$ maka variabel ROE dinyatakan tidak terjadi multikolonieritas.

c. Nilai VIF untuk variabel EPS 3,525 < 10 dan nilai tolerance 0,284 > 0,100 maka variabel EPS dinyatakan tidak terjadi multikolonieritas.

d. Nilai VIF untuk variabel Volume Perdagangan 2,832 < 10 dan nilai tolerance 0,353>0,100 maka variabel Volume Perdagangan dinyatakan tidak terjadi multikolonieritas.

\section{Analisis Regresi Berganda}

Tabel 6. Hasil Uji Regresi Berganda

\begin{tabular}{|c|c|c|c|c|c|c|c|}
\hline \multirow[t]{2}{*}{ Model } & \multicolumn{2}{|c|}{$\begin{array}{c}\text { Unstandardized } \\
\text { Coefficients }\end{array}$} & \multirow{2}{*}{$\begin{array}{c}\text { Standardized } \\
\text { Coefficients } \\
\text { Beta }\end{array}$} & \multirow[t]{2}{*}{$\mathbf{T}$} & \multirow[t]{2}{*}{ Sig. } & \multicolumn{2}{|c|}{$\begin{array}{c}\text { Collinearity } \\
\text { Statistics } \\
\end{array}$} \\
\hline & B & Std. Error & & & & Tolerance & VIF \\
\hline (Constant) & $-1800,270$ & 933,614 & & $-1,928$ & 0,062 & & \\
\hline ROA & 3458,360 & 907,711 & 0,497 & 3,810 & 0,001 & 0,148 & 6,747 \\
\hline ROE & $-279,978$ & 146,305 & $-0,259$ & $-1,914$ & 0,064 & 0,138 & 7,234 \\
\hline EPS & 13,638 & 1,709 & 0,753 & 7,980 & 0,000 & 0,284 & 3,525 \\
\hline
\end{tabular}


Volume

Perdagangan

$$
-0,000 \quad 0,000
$$

$-0,144-1,699 \quad 0,098$

$0,353 \quad 2,832$

a. Dependent Variable: Harga Saham

Berdasarkan tabel hasil perhitungan regresi linier tersebut diatas maka dapat disusun persamaan regresi linier berganda sebagai berikut :

Berdasarkan tabel perhitungan regresi linier di atas, dapat disusun persamaan regresi linier berikut:

$$
Y=-1800,270+3458,360 X_{1}-279,978 X_{2}+13,638 X_{3}-0,000 X_{4}
$$

Maksud dan penjelasan nilai koefisien regresi tersebut dapat dijelaskan sebagai berikut:

a) Dalam persamaan koefisien regresi diatas, nilai konstanta sebesar $-1800,270$ mengartikan bahwa jika nilai ROA, ROE, EPS, Volume Perdagangan nilainya adalah 0, maka harga saham (Y) nilainya adalah $-1800,270$.

b) Koefisien regresi $X_{1}$ atau variabel ROA sebesar 3458,360, hal ini menunjukkan jika setiap kenaikan $1 \%$ variabel ROA, sementara variabel ROE,EPS, Volume Perdagangan diasumsikan tetap, maka besarnya Harga Saham akan mengalami kenaikan sebesar 3458,360.

c) Koefisien regresi $X_{2}$ atau variabel $\mathrm{ROE}$ sebesar $-279,978$, hal ini menunjukkan jika setiap kenaikan $1 \%$ variabel ROE, sementara variabel ROA, EPS, Volume Perdagangan diasumsikan tetap, maka besarnya Harga Saham akan mengalami penurunan sebesar -279,978.

d) Koefisien regresi $X_{3}$ atau variabel EPS sebesar 13,638, hal ini menunjukkan jika setiap kenaikan $1 \%$ variabel EPS, sementara variabel ROA, ROE, Volume Perdagangan diasumsikan tetap, maka besarnya Harga Saham akan mengalami peningkatan sebesar 13,638.

e) Koefisien regresi $\mathrm{X}_{4}$ atau variabel Volume Perdagangan sebesar $-0,000$, hal ini menunjukkan jika setiap kenaikan 1\% variabel Volume Perdagangan, sementara variabel ROA, ROE. EPS diasumsikan tetap, maka besarnya Harga Saham akan mengalami peningkatan sebesar 0,000 .

\section{Analisis Koefisien Determinasi $\left(\mathbf{R}^{2}\right)$}

Tabel 7. Hasil Uji Koefisien Determinasi

Anova $^{b}$

\begin{tabular}{rrrrrr}
\hline Model & R & R Square & $\begin{array}{c}\text { Adjusted R } \\
\text { Square }\end{array}$ & $\begin{array}{c}\text { Std. Error of } \\
\text { the Estimate }\end{array}$ & $\begin{array}{l}\text { Durbin- } \\
\text { Watson }\end{array}$ \\
\hline 1 & $0,955^{\mathrm{a}}$ &, 912 & 0,902 & 1652,449 & 1,371 \\
\hline
\end{tabular}

a. Predictors: (Constant), Volume Perdagangan, EPS, ROA, ROE

b. Dependent Variable: Harga Saham 
Menurut Tabel 7, nilai Adjusted $\mathrm{R}^{2}$ adalah 0,902 atau 90,2\%. Hal tersebut menunjukkan bahwa pengaruh variabel ROA, ROE, EPS dan volume perdagangan sebesar 90,2\%. Sisa 100\%$90,2 \%=9,8 \%$ dijelaskan oleh faktor lainnya yang tidak termasuk diteliti dalam penelitian ini.

\section{Uji Hipotesis}

\section{Hasil Uji Signifikansi Parsial (Uji Statistik T)}

\section{Tabel 8. Hasil Uji Parsial}

Coefficients $^{\text {a }}$

\begin{tabular}{lrrrrr}
\hline Model & \multicolumn{2}{c}{$\begin{array}{c}\text { Unstandardized } \\
\text { Coefficients }\end{array}$} & $\begin{array}{c}\text { Standardized } \\
\text { Coefficients }\end{array}$ & T & Sig. \\
& \multicolumn{1}{c}{ B } & Std. Error & \multicolumn{1}{c}{ Beta } & & \\
\hline (Constant) & $-1800,270$ & 933,614 & $-1,928$ & 0,062 \\
ROA & 3458,360 & 907,711 & 0,497 & 3,810 & 0,001 \\
ROE & $-279,978$ & 146,305 & $-0,259$ & $-1,914$ & 0,064 \\
EPS & 13,638 & 1,709 & 0,753 & 7,980 & 0,000 \\
Volume & $-0,000$ & 0,000 & $-0,144$ & $-1,699$ & 0,098 \\
Perdagangan & & & & &
\end{tabular}

a. Dependent Variable: Harga Saham

Hasil dari tabel tersebut dapat dijelaskan sebagai berikut :

1) ROA merupakan variabel yang mempengaruhi harga saham. Nilai t hitung variabel ROA adalah 3,810 > 2,030 (t tabel) atau sign. 0,001 < 0,050. Dengan demikian, dapat disimpulkan bahwa variabel ROA berpengaruh signifikan terhadap harga saham.

2) ROE secara statistik tidak mempengaruhi harga saham. Perhitungan t test ROE adalah 1,914 $<\mathrm{t}$ tabel 2,030 atau sign. 0,064 > 0,050. Dengan demikian dapat disimpulkan bahwa variabel ROE tidak berpengaruh terhadap harga saham.

3) EPS menghasilkan hubungan yang mempengaruhi harga saham. Pengujian t test menghasilkan nilai t EPS 7,980 > 2,030 atau sig. 0,000 < 0,050. Dengan demikian dapat disimpulkan bahwa variabel earning per share berpengaruh terhadap harga saham.

4) Volume perdagangan merupakan variabel yang tidak mempengaruhi harga saham. Variabel volume perdagangan mempunyai nilai $t_{\text {hitung }}$ sebesar $-1,699<\mathrm{t}_{\text {tabel }} 2,030$ atau $0,098>0,050$. Maka disimpulkan bahwa variabel volume perdagangan berpengaruh negatif dan tidak signifikan secara parsial terhadap harga saham. 


\section{Hasil Uji Signifikansi Simultan (Uji Statistik F)}

\section{Tabel 9. Hasil Uji Simultan}

ANOVA ${ }^{b}$

\begin{tabular}{rlrrrrr}
\hline Model & & Sum of Squares & Df & Mean Square & F & Sig. \\
\hline \multirow{2}{*}{1} & Regression & 986791253,140 & 4 & 246697813,285 & 90,346 & $0,000^{\mathrm{a}}$ \\
& Residual & 95570577,862 & 35 & 2730587,939 & & \\
& 1082361831,00 & 39 & & & \\
\multicolumn{2}{c}{ Total } & 2 & & & & \\
$\begin{array}{l}\text { a. Predictors: (Constant), Volume Perdagangan, EPS, ROA, ROE } \\
\text { b. Dependent Variable: Harga Saham }\end{array}$
\end{tabular}

Tabel 9 menunjukkan bahwa variabel independen secara bersama-sama memiliki pengaruh yang signifikan terhadap variabel dependen. Hal tersebut dapat dibuktikan dengan Fhitung 90,346 > F tabel 2,64 dan nilai signifikan (sig.) sebesar 0,000 < 0,050. Dengan demikian Ha diterima, sehingga dapat dikatakan ROA, ROE, EPS dan volume perdagangan secara bersamasama berpengaruh terhadap harga saham perbankan.

\section{PEMBAHASAN}

\section{Pengaruh ROA terhadap Harga Saham}

ROA berpengaruh positif dan signifikan terhadap harga saham perusahaan perbankan. Berdasarkan hasil uji-t didapatkan t-test ROA sebesar 3,810 > t-tabel 2,030 atau sig. 0,001 < 0,050. Artinya Ha diterima dan Ho ditolak. ROA mengacu pada kemampuan perusahaan untuk memanfaatkan aset yang digunakannya. ROA muncul dari rasio laba bersih setelah pajak terhadap total aset. Dengan demikian, ROA perusahaan akan semakin tinggi, nilai aset perusahaan juga akan semakin tinggi, dan karena banyaknya kebutuhan investor dalam dan luar negeri, maka akan menghasilkan harga saham yang lebih tinggi. Penelitian Rosdian Widiawati Watung (2016) menunjukkan bahwa return on asset berpengaruh positif dan signifikan. Penelitian ini berjudul Pengaruh Return On Asset, Laba Bersih dan Laba Bersih Per Saham terhadap Harga Saham Perusahaan Perbankan di Indonesia periode 2011-2015. Hasil statistik (uji-t) menunjukkan bahwa ROA berpengaruh signifikan terhadap harga saham perusahaan perbankan di Bursa Efek Indonesia periode 2011-2015, artinya dapat disimpulkan bahwa return on asset berpengaruh signifikan terhadap harga saham, yang mendukung hipotesis penelitian. 


\section{Pengaruh ROE terhadap Harga Saham}

Nilai signifikansi atas variabel ROE diketahui senilai 0,064 yang lebih besar dari 0,050 berarti variabel ROE tidak berpengaruh signifikan. Hasil penelitian menunjukkan bahwa return on equity perusahaan tidak menyebabkan harga saham menjadi naik. Artinya kenaikan atau penurunan rate pengembalian saham tidak akan berpengaruh secara langsung terhadap harga saham. Studi Evan Andreanto Wibowo (2016) juga menegaskan bahwa pengaruh ROE dapat diabaikan atau tidak signifikan.

\section{Pengaruh EPS terhadap Harga Saham}

Dari hasil uji t yang dilakukan nilai sebesar 7,980 $>\mathrm{t}_{\text {tabel }} 2,030$ atau 0,000 $<0,050$ yang artinya variabel EPS mempunyai pengaruh yang signifikan terhadap harga saham perbankan. Koefisien regresi EPS yaitu mempunyai arah positif yaitu sebesar 13,638. Hal ini menunjukan bahwa kenaikan sebesar 1\% pada variabel EPS maka harga saham akan mengalami kenaikan sebesar 13,638\%. Hal ini sesuai dengan penelitian yang dilakukan oleh Catarina Putri Mariska (2015) yang hasilnya nilai t sebesar 15,667 dengan tingkat signifikansi 0,000 0,050.

\section{Pengaruh Volume Perdagangan Terhadap Harga Saham}

Hasil penelitian Sugeng Abidin (2016) menunjukkan bahwa volume perdagangan mempunyai pengaruh negatif dan tidak signifikan terhadap harga saham, dan hasil penelitian volume perdagangan yang mempunyai pengaruh negatif signifikan terhadap harga saham perusahaan yang termasuk dalam IDX30-index. Peningkatan volume perdagangan mencerminkan peningkatan penawaran dan permintaan saham.

\section{Pengaruh ROA, ROE, EPS dan Volume Perdagangan terhadap Harga Saham.}

Berdasarkan hasil pengujian yang dilakukan, ditemukan bahwa Return On Asset, Return On Equity, Earning Per Share, dan Volume Perdagangan secara bersama-sama berpengaruh positif terhadap harga saham. Hal ini dibuktikan pada tabel 4.9 diperoleh $F_{\text {hitung }} 90,346>F_{\text {tabel }}$ 2,64 dan nilai signifikan (sig.) sebesar $0,000<0,050$.

Pemaparan diatas berarti ROA, ROE, EPS dan Volume Perdagangan secara bersama-sama berpengaruh positif dan signifikan terhadap harga saham. Maka dari itu jika kombinasi ROA, ROE, EPS dan Volume Perdagangan tinggi secara bersama-sama akan memberikan pengaruh positif yang besar terhadap harga saham. 


\section{KESIMPULAN}

Kesimpulan yang dapat ditarik dari penelitian ini meliputi :

1. ROA berpengaruh positif secara parsial terhadap harga saham perusahaan perbankan di Bursa Efek Indonesia tahun 2015-2018 dengan nilai signifikansi 0,001.

2. ROE berpengaruh negatif secara parsial terhadap harga saham perusahaan perbankan di Bursa Efek Indonesia tahun 2015-2018 dengan nilai signifikansi 0,064.

3. EPS berpengaruh positif secara parsial terhadap harga saham perusahaan perbankan di Bursa Efek Indonesia tahun 2015-2018 dengan nilai signifikansi 0,000.

4. Volume perdagangan berpengaruh negatif secara parsial terhadap harga saham perusahaan perbankan di Bursa Efek Indonesia tahun 2015-2018 dengan nilai signifikansi 0,098.

5. Hasil perhitungan uji F, berdasarkan hasil perhitungan dengan menggunakan program SPSS diperoleh $\mathrm{F}_{\text {hitung }}$ 90,346 > $\mathrm{F}_{\text {tabel }}$ 2,69 dengan signifikansi 0,000 ( $\left.\mathrm{P}<0,05\right)$, sehingga Ho diterima dan Ha ditolak. Dengan kata lain bahwa hipotesis kedua terbukti bahwa Return On Asset, Return On Equity, Earning Per Share dan Volume perdagangan secara simultan berpengaruh terhadap harga saham di perusahaan perbankan di Bursa Efek Indonesia.

\section{Saran}

Masukan atau saran yang penulis sampaikan sebagai respon atas hasil penelitian ini yaitu: 1. Sebaiknya perusahaan memperhatikan nilai perolehan modal karena hal ini dapat mendorong investor untuk mengambil keputusan investasi. Yang terbaik adalah meningkatkan level manajemen bisnis dalam hal pengelolaan sumber pendanaan operasional untuk memaksimalkan keuntungan. Oleh karena itu, hal ini berdampak pada kepentingan investor dalam menanamkan modalnya pada perusahaan.

2. Investor tidak menggunakan volume perdagangan sebagai informasi investasi karena volume perdagangan terbukti tidak berpengaruh terhadap harga saham.

3. Bagi peneliti lain. Diharapkan selain variabel seperti ROA, ROE, EPS dan volume perdagangan akan ditambahkan variabel lain, serta variabel lain yang berhubungan dengan harga saham, agar lebih memahami faktor-faktor apa saja yang akan mempengaruhi harga saham. Selain itu, perlu dilakukan penelusuran dan pemeriksaan ulang dengan subjek uji lainnya dari bisnis perbankan, dan menambah periode riset yang lebih lama untuk sampai pada hasil penelitian yang memuaskan. 


\section{DAFTAR PUSTAKA}

Fahmi, Irham.2015. Analisis Laporan Keuangan. Cetakan 5. Bandung : Alfabeta.

Fahmi, Irham. 2015. Manajemen Investasi Teori dan Soal Jawab. Edisi 2.Jakarta. Salemba Empat

Ghozali, Imam.2011. Aplikasi Analisis Multivariate dengan program IBM SPSS 19. Semarang:Badan Penerbit Universitas Diponegoro.

Halim, Abdul (2003). Analisis Investasi. Jakarta: Salemba Empat.

Husnan, Suad.2011. Dasar-dasar Teori Portofolio dan Analisis Sekuritas. Yogyakarta:BPFE-UGM

Indriani, N. P. L., \& Dewi, S. K. S. (2016). Pengaruh Variabel Tingkat Kesehatan Bank Terhadap Harga Saham Perbankan Di Bursa Efek Indonesia. E-Jurnal Manajemen, 5(5).

Jayanti, E. D. (2015). Pengaruh Return On Investment (Roi), Earning Per Share (Eps), Dan Price Earning Ratio (Per) Terhadap Harga Saham Perusahaan Pertambangan Yang Terdaftar Di Bei Tahun 2011-2013 (Doctoral dissertation, Stie Perbanas Surabaya).

Kasmir. 2016. Analisis Laporan Keuangan. Edisi 1 Cetakan 6. Jakarta: PT Raja Grafindo Persada.

Mukti, Prabowo. 2018. Pengaruh Return On Invesment, Earning Per Share, dan Return On Equity Terhadap Harga Saham Perusahaan Manufaktur Yang Terdaftar di BEI Tahun 2013-2016. Jurnal Ekobis Dewantara Vol.1 No.1:73.

Octaviani, S., \& Komalasari, D. (2017). Pengaruh Likuiditas, Profitabilitas, dan Solvabilitas Terhadap Harga Saham. JAK (Jurnal Akuntansi): Kajian Ilmiah Akuntansi, 4(1).

Rahayu, T. N. (2019). Pengaruh Tingkat Suku Bunga, Nilai Tukar Rupiah dan Volume Perdagangan Saham Terhadap Harga Saham Perusahaan Manufaktur. Paradoks: Jurnal Ilmu Ekonomi, 2(2), 35-46.

Sugiyono, (2016). Metode Penelitian Kuantitatif, Kualitatif, Dan R\&D. Bandung:Alfabeta,cv Syamsuddin, (2009). Manajemen Keuangan Perusahaan. Jakarta: PT Raja Grafindo Persada.

Watung, R. W., \& Ilat, V. (2016). Pengaruh Return On Asset (Roa), Net Profit Margin (Npm), Dan Earning Per Share (Eps) Terhadap Harga Saham Pada Perusahaan Perbankan Di Bursa Efek Indonesia Periode 2011-2015. Jurnal EMBA: Jurnal Riset Ekonomi, Manajemen, Bisnis dan Akuntansi, 4(2).

Wulandari, D. (2015). Analisisis Pengaruh Earning Per Share (Eps), Return On Equity (Roe), Debt To Equity Ratio (Der) Terhadap Harga Saham Pada Perusahaan Transportation Services Yang Terdaftar Di Bursa Efek Indonesia (Bei) Tahun 2010-2013 (Doctoral dissertation, Universitas Muhammadiyah Surakarta).

www.idx.co.id 